\title{
Andrei SIMUT,
}

\section{Contemporary Representations of Artificial Intelligence in Science Fiction Films, Visual Arts and Literature. A Short Introduction}

Abstract: The article is a short introduction in the problems of science fiction genre, posthumanism and a short presentation of the articles of the present volume.

Keywords: science fiction, cyborg film, posthumanism.

\section{Andrei SIMUT}

Babes-Bolyai University

E-mail: andrei.simut@gmail.com

EKPHRASIS, 1/2017

Ghosts IN The Cinema Machine pp. 5-8

DOI:10.24193/ekphrasis.17.1

Published First Online: 2017/06/30
From Metropolis (1927) to Ex Machina (2015), from A Space Odyssey (1968) to The Matrix (1999), from Blade Runner (1982) to Her (2013), science fiction cinema has imagined countless modes of narrating the uncanny interaction between man and machine, one so strange yet so familiar to any smartphone user.

To a certain degree, Baudrillard's premise has proven prophetic: with the rapid advance of technologies, the science fiction universe, once placed in a distant future, was challenged by the present day realities and the unexpected (yet so many times imagined) fulfillment of the technological utopias. The current issue of Ekphrasis started from the premise that we are witnessing a transformation, although almost unnoticeable, of science fiction films, triggered by the rapid advancement of technology and its irreversible intrusion in our daily existence. However, this continuous transformation was 
a staple of SF from its very beginnings as a genre, but we were interested in the particular stylistic or iconological forms of this transformation of contemporary visual arts. The theoretical reflection upon these questions would lead to a better understanding of the role and purpose of science fiction in a technologically saturated environment.

The nature of classic science fiction was prospective. The most important definitions of the genre insisted upon the fact that its creative energy stems from its capacity to generate critical distance towards the present (seen as historical- in this respect, SF is a literary descendant of the historical novel), towards our custom perceptions (the "sense of wonder" and "cognitive estrangement"). A few theorists have defined SF as a mode rather than a genre. For example, Csicsery-Ronay considers it a "mode of awareness", noticing the same inner gap regarding the science fiction representation of a non-existing time (the future) (Csicsery-Ronay, 1991). For Jameson, the main deficiency of the genre is the difficulty of imagining the radical otherness of the future, its tendency to return to the familiar (Csicsery-Ronay, 1991), which is, in my opinion, an important feature of contemporary science fiction film, from TV series like Black Mirror, Humans, The Leftovers or Westworld to feature films like La Piel que habito, Her, Ex Machina, Gravity. Black Mirror represents the significant example for the implosion of the prospective dimension of contemporary SF. The HBO series Westworld, a re-creation of Michael Crichton classic from 1973 is the perfect baudrillian example: the implosion of the distance between real and hiperreal, between human and posthuman (a homogenization emphasized by the HBO series), between historical past and present and, eventually between cinematographic genres (western or science fiction). Westworld is significant for various other reasons: the critical potential of science fiction through its allegorical dimension (pointing at the female cyborgs exploitation, alluding at the fact that the theme park is a male phantasy, marred by violence and dark sexual impulses, hinting at the class system and inequalities), its openness to philosophical questions regarding the nature of man, consciousness, free will. It is also significant for the great ability of science fiction to adapt to the new technical realities, to find new realms of the uncanny. In this respect, the posthuman narratives offer substance for reconquering what was thought to be lost from SF, the possibilities of distance, of prospect, the creative output for the "cognitive estrangement": human consciousness - simulated consciousness, dystopian and utopian visions on posthumanism, transhumanist utopia, transgressions (data made flesh, flesh made data). On the other hand, the posthumanist narratives imply the critical reflection upon the philosophical dimension of the idea of man, considered by the transhumanist utopians to be an historical idea which must be transgressed (Besnier, 2009, 71).

However, a few questions still remain: are we witnessing the radical transformation of the sci-fi genre, or the end the classical "artificial intelligence" trope? Has scifi been reduced to a mere projection/allegory of the "real" world? What is the future of the genre, after assimilating fantasy (Star Wars), horror, or dystopia? What is the 
future of sci-fi narratives in the wake of blockbusters like Gravity, TV series such as Black Mirror or Humans or auteur films such as Her? What is left of the realm of extrapolation?

Starting from these questions, our current issue of Ekphrasis investigates what is left of the traditional imagination of science fiction after being surpassed by the evolution of hyperreality/ virtual reality and other simulated spaces. To our surprise as editors, the articles we received and accepted have offered a high level of coherence regarding both the thematic concerns and even the chosen examples for the case studies involved (films like Ghost in the Shell 2, Her, Ex Machina, Advantageous). However, the theoretical aspects of the topic were not neglected. Our issue begins and concludes with two articles focusing on key conceptual problems: Doru Pop employs the metaphoric syntagm "ghost in the cinema machine" both in the direction of SF and its technophobic (and eventually posthuman) obsession with the animated machines, and especially as far as the nature of the visual experience is concerned. Doru Pop's article tackles the significant differences of each mode of imagination and immersion corresponding to each visual art (film, graphic novel, video game). The other important theoretical article of this volume, written by Mircea Valeriu Deaca, attempts to redefine science fiction genre, to question its autonomy (as compared to other genres) and to offer an in-depth analysis of its cognitive effects on the viewer. The other three articles, written by Kathy Nguyen, Elisabetta Di Minico and Sennah Yee consider the ideological counterpart of science fiction, concentrating on the problematic representations of feminine characters (cyborgs or AIs) in cyborg film, as a subgenre of science fiction.

Doru Pop compares the viewer's experiences of contemporary visual media choosing Ghost in the Shell as a case study, since it offers a similar narrative structure through various modes of representation (film, animated cartoon, graphic novel or video game). Starting from Derrida's premise (what we imagine is never the image that we see), the author compares different modalities of image representation and imagination, proposing the concept of cinematic modalities experienced by the film spectator, in search of the significant differences between each visual art and its specific mode of immersion. His article is a brilliant theoretical framework for our daily experience and modes of immersion into the "phantasmagoria of specters", our experience of reality through the "technologies of spectrality".

Kathy Nguyen analyses the modes of transgressing the dichotomies between the $\mathrm{im} /$ material and immortalized information and terminal fleshy bodies, how bodies become innate scions, how flesh is transfigured into information, how bodies are upgraded in films like Ghost in the Shell 2 Innocence, inspired by Japanese anime/manga or independent films such as Advantageous by Jennifer Phang.

Luiza Filimon focuses on the narrative analysis of Ghost in the Shell 2: Innocence, the film featuring exclusively posthuman characters, and the problems regarding the posthuman identity as compared with notions of affects or sense of the self. The most interesting part of the article is not only the analysis of the intertextual dimension of 
Mamoru Oshii's film (from La Rochefocault to Plato and the Bible), but especially the similarities with other literary works such as Raymond Roussel's Locus Solus or L'Isle Adam's L'Ève Future.

Elisabetta Di Minico discusses the gender issues implied in the cinematographic representation of the confrontation between human and non-human, with the purpose of interpreting the reasons for the double male fear (of technology and women), the possible elements of gender power relations in the dystopian/science fictional genre, focused especially on Ex Machina (2015).

Sennah Yee focuses on contemporary representations of feminine cyborgs in films such as Her, Ex Machina, that is, films which feature male human protagonists and non-human females. Starting from the assumption that cinema has shown since Méliès the signs of a "patriarchal apparatus", she observes that the male gaze is maintained even in these films that have the intention of questioning it. The representations of female cyborgs or AIs in mainstream cinema remain, in her opinion, hypersexualised.

Mircea Valeriu Deaca offers new insights of science fiction as a genre, a clear overview on its specificity through functional cognitive models, revising the problem of the autonomy of the genre, considered to be reliant on other "basic genre construals" like action, drama, comedy or on "functional bundles" (Grodal's concept) in order to re-define the cognitive effect of the SF iconography.

Ioan Buteanu discusses the ambiguous role and representation of technology both from a cultural and a cinematographic perspective, referring especially to the films of "survival genre' and dystopian trend.

\section{References:}

1. Baudrillard, Jean. "Two Essays. Simulacra and Science Fiction". Science Fiction Studies, Vol. 18, November 1991.

2. Csicsery-Ronay, Istvan. "The Sf of Theory - Baudrillard and Harraway". Science Fiction Studies, Vol. 18, No. 13, Nov. 1991.

3. Dinello, Daniel. Technophobia! Science Fiction Visions of Posthuman Technology. Austin: University of Texas Press, 2005

4. Dufresne, Jacques. Après l'homme, le cyborg. Quebec: Editions Multimondes, 1999.

5. Haney W. S.. Cyberculture, Cyborgs, and Science Fiction. Consciousness and the Posthuman. Amsterdam \& New York: Rodopi, 2006.

6. Jameson, Fredric. Archaeologies of the Future. The Desire Called Utopia and other Science Fictions. London and New York: Verso, 2005.

7. Parrinder, Patrick (Ed.). Learning from Other Worlds. Estrangement, Cognition, and the Politics of Science fiction and Utopia. Liverpool: Liverpool University Press, 2000.

8. Suvin, Darko. Metamorphoses of Science Fiction. On the Poetics and History of a Literary Genre. New Haven and London: Yale University Press, 1979. 